\title{
THE LIFE HISTORY OF EPERETMUS TYPUS BIGELOW AND THE SYSTEMATICS OF THE FAMILY OLINDIADIDAE (LIMNOMEDUSAE)
}

AUTHOR(S):

Nagao, Zen

CITATION:

Nagao, Zen. THE LIFE HISTORY OF EPERETMUS TYPUS BIGELOW AND THE SYSTEMATICS OF THE FAMILY OLINDIADIDAE (LIMNOMEDUSAE). PUBLICATIONS OF THE SETO MARINE BIOLOGICAL LABORATORY 1973, 20: 89-102

ISSUE DATE:

1973-12-19

URL:

http://hdl.handle.net/2433/175787

RIGHT: 


\title{
THE LIFE HISTORY OF EPERETMUS TYPUS BIGELOW AND THE SYSTEMATICS OF THE FAMILY OLINDIADIDAE (LIMNOMEDUSAE)
}

\author{
ZEN NAGAO \\ Kushiro Branch, Hokkaido University of Education, Kushiro, Hokkaido, 085 Japan
}

With 15 Text-figures

The olindiadiid medusa, Eperetmus typus was first described by BIGELOw (1915) as a new species of a new genus from Alaska based on a single medusa. Since then this species has sometimes been reported from the northern Pacific; two specimens from Alaska (BIGELow, 1920), several specimens from Vancouver (FoERSTER, 1923), three and many specimens from Hokkaido, northern Japan (UCHIDA, 1929, 1940), one specimen from Friday Harbor (MACKIE and MACKIE, 1963). All of them are the records of the medusan stage. Recently, the author found the hydroid colonies of this species from Akkeshi Bay, Hokkaido, and successfully reared the medusae liberated from these hydroids till matured (NAGAO, 1969a). On the one hand, from May to November in 1966 and 1967, many medusae of Eperetmus typus in various developmental stages were obtained by surface tows in the bay. The young medusae obtained by the surface tows coincided with the young medusae reared in the laboratory.

The present paper deals mostly with the development of the medusan stage and the systematic considerations of the family Olindiadidae.

\section{The Hydroid}

The colonies of Eperetmus typus were usually found on the tubes of a sedentary polychaetous Hydroides ezoensis attached to the empty shells of Crassostrea gigas, though some colonies were found on the inner surface of empty shells of a bivalve Callithaca adamsi or along the grooves of the shells of a gastropod, Fusitritonoregonensis, inhabited by a hermit-crab Pagurus pectinatus. All these shells were obtained from 3-4 $\mathrm{m}$ deep by dredging in the innermost part of Akkeshi Bay from April to July in 1965-67.

The colonies and hydroids with medusa buds were described in detail in the previous paper (NAGAO, 1969a). The characteristics of the hydroid are briefly summarized as follows. The colonies are small, being composed of up to about 10 polyps (Fig. 1). The stolon is rather thick, not forming a network. The hydroids (Fig. 2) are very small $0.3-0.5 \mathrm{~mm}$ high and $0.12-0.15 \mathrm{~mm}$ wide. The tentacle is only one, long and filiform. The nematocysts are irregularly distributed on the whole shaft. 
The movement of the tentacle is very slow. Below the tentacle, the stem is covered with a very thin membranous sheath. One medusa bud is borne at the base of the hydroid at a time from April to July. In the laboratory, twenty to thirty days after its appearance young medusa is liberated from the hydroid at water temperature of $11^{\circ}-12^{\circ} \mathrm{C}$. Neither a planula-like bud nor a frustule was produced from the stem during the rearing of colonies. The hydroid is milky white or yellowish grey in color.

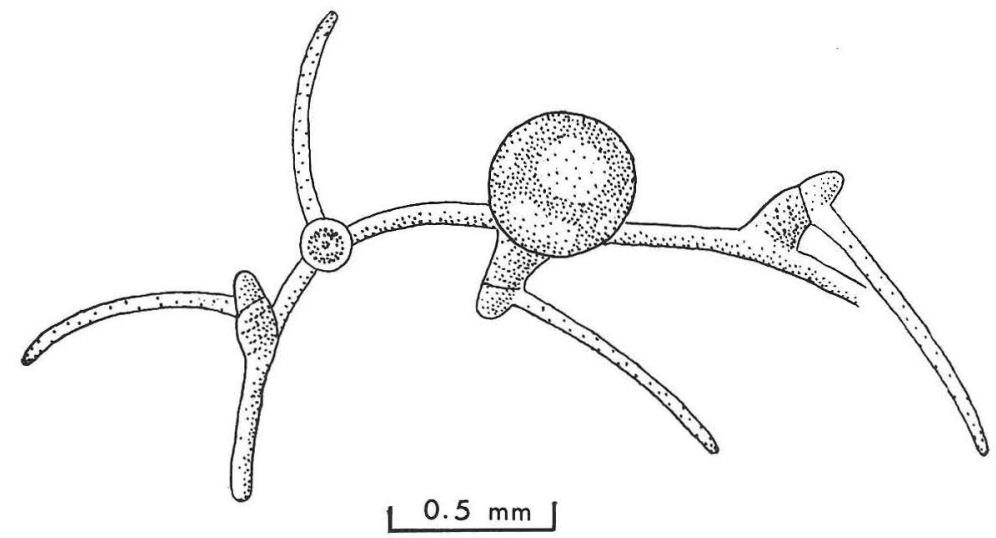

Fig. 1. A part of hydroid colony of Eperetmus typus.

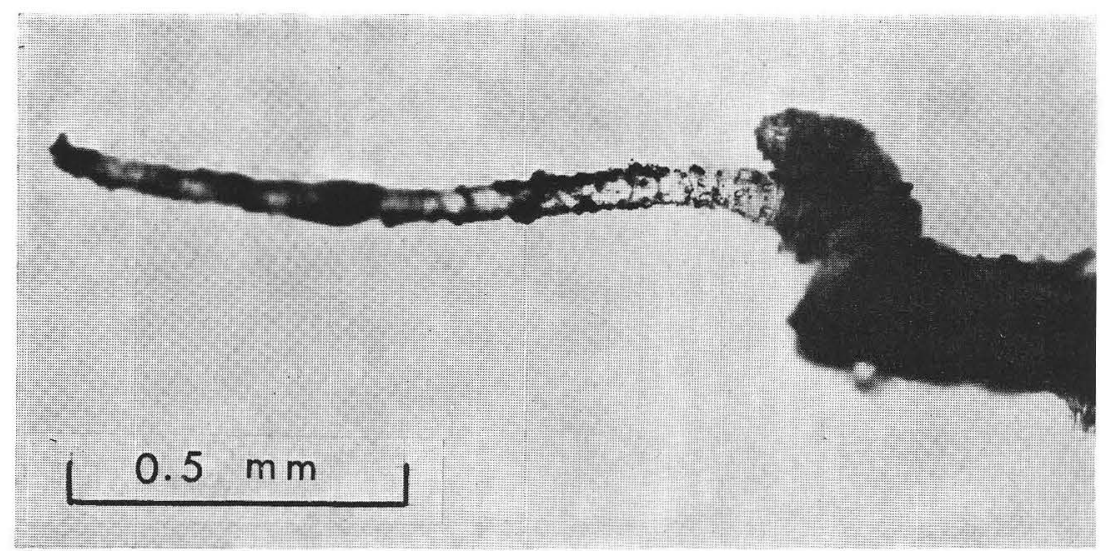

Fig. 2. A hydroid of Eperetmus typus.

\section{Metamorphosis of the Medusa}

1) Young Medusae Newly Liberated: In the laboratory, four young medusae were liberated from the hydroids in July 1965. In 1966 one medusa in June, eight ones in July and seven in early August were set free from the hydroids. 
The description of the newly liberated medusae in the previous paper is here repeated for the comparison with the later metamorphosis. When just liberated from the hydroid (Figs. 3,4), the umbrella is bell-shaped, about as high as wide or slightly wider than high, $0.7-1.0 \mathrm{~mm}$ high and about $1.0 \mathrm{~mm}$ wide. Frequently the apical part of the umbrella is projected slightly. The jelly is moderately thick and the nematocysts are scattered over the exumbrellar surface. The stomach is funnelor bowl-shaped, 1/5-1/6 the height of the subumbrellar cavity and sometimes the mouth
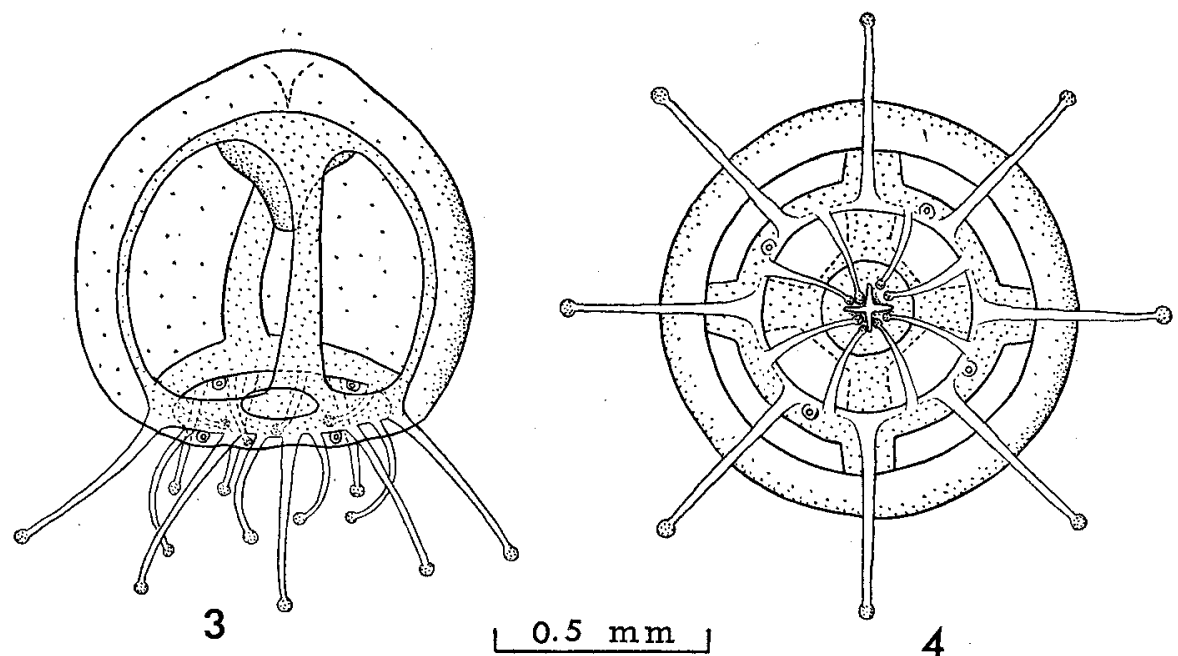

Figs, 3 and 4. Young medusa newly liberated. 3. Side view. 4. Oral view.

part is protruded. Radial canals are broad, increasing slightly the width toward the ring canal which is fairly broad, too. There are 4 perradial, 4 interradial and 8 adradial marginal tentacles. Of these, the perradial and the interradial tentacles are older and longer than the adradial ones which are directed centripetally. All tentacles arise directly from the umbrellar margin. Any indications of centripetal canals, characteristic of adult medusae, are not yet seen. Each tentacle has one nematocyst cluster only at the terminal end. There are four marginal vesicles, each with a concretion. When viewed the umbrellar margin from the oral side and numbered the tentacles in a clockwise order the marginal vesicles are located, each between the first adradial tentacle and the interradial one in each quadrant (Fig. 4). The adradial tentacles in octants including the marginal vesicle are slightly dislocated from the precise adradii towards the perradii, while those in octants without the marginal vesicle are dislocated slightly towards the inerradii. The velum is wide. The subumbrellar surface, the stomach, the radial and ring canals and the tentacles are pale yellow or yellowish grey in color. The young medusae are fairly active, swimming intermittently.

2) Development of Tentacles and Marginal Vesicles: The observations on the 
metamorphosis of the medusa were made mostly on the specimens obtained by surface tows.

As described above the newly liberated medusae have already four cycles of marginal tentacles: 4 perradial, 4 interradial and $4+4$ adradial tentacles. In the successive stages, the marginal tentacles increase one by one in each quadrant keeping the same order in both octants and maintaining the cyclic symmetry with the interradius as the center, as shown in Fig. 5. Thus, the total number of tentacles at each cycle is as follows: $16(\mathrm{IV}), 20(\mathrm{~V}), 24(\mathrm{VI}), 28(\mathrm{VII}), 32$ (VIII), 36(IX), 40(X), 44(XI), . . . The sequence, however, gradually becomes irregular after the 13th tentacle's stage (52 tentacles in total). There are often found some deviation from the normal sequence such as reversal of the normal order and isochronous development in successive tentacles. After the 20th tentacle's stage ( 80 tentacles in total) the sequence becomes very irregular. In fully grown medusae $22-40$ tentacles are counted in each quadrant.

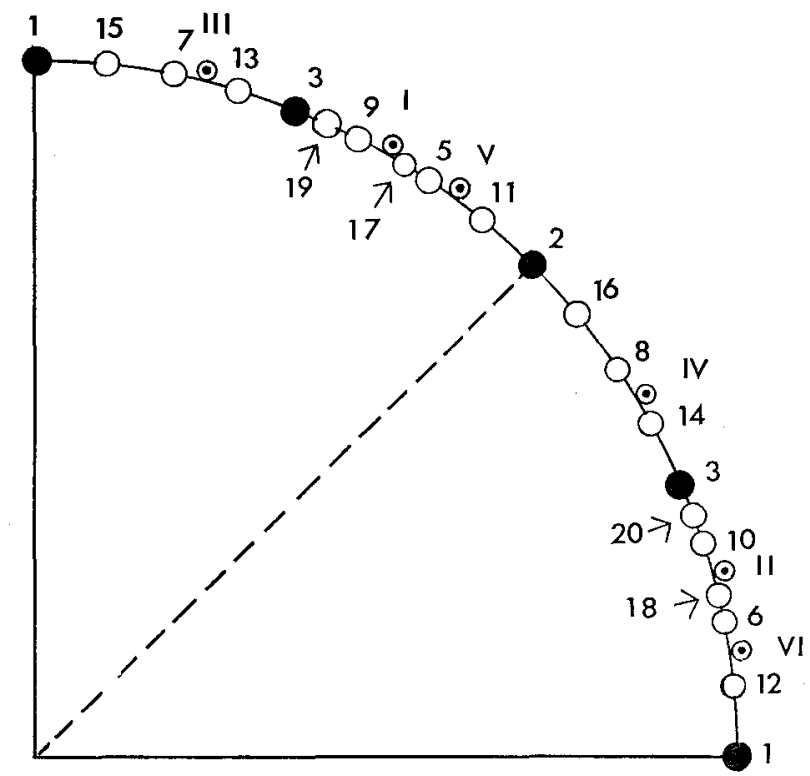

Fig. 5. Diagram showing the subsequent appearances of tentacles and marginal vesicles in a quadrant from the oral side.

The marginal vesicles increase with age also one by one in each quadrant in the same order of cyclic symmetry as in tentacles till the sixth marginal vesicle appears, as shown in Fig. 5. When the young medusae are liberated from the hydroid the first marginal vesicles are already seen as described above; however, the successive development of vesicles is very slow and lags far behind that of the tentacles till about the 20th tentacle's stage. The second vesicle develops at the 6-8th tentacle's stage and the third one appears at the 10-13th tentacle's stage. The fourth and the successive 
vesicles develop after the 16th tentacle's stage. And at the 20th tentacle's stage the medusae have 10 to 14 marginal vesicles in each quadrant. After the 20th tentacle's stage the marginal vesicles increase quickly in number, and gradually become located nearly alternately with tentacles.

In the following sections the developmental changes will be described in relation to the sequence of the development of tentacles described above.

3) Umbrella: The umbrella increases rapidly in size with age, and gradually becomes flattened. When fully grown it attains $14-16 \mathrm{~mm}$ high and $22-26 \mathrm{~mm}$ in diameter. The ratio between the height and the width of the umbrella is about $1: 1$ till about the 8th tentacle's stage. It comes to $1: 1.2$ at the 10th tentacle's stage, then changes to $1: 1.3-1.4$ at the 13th tentacle's stage. After the 18th tentacle's stage the umbrella assumes an adult form with the ratio nearly $1: 1.5$ in specimens preserved in $4 \%$ formaldehyde in sea water. The umbrella of living medusae is flatter than in preserved specimens.

The exumbrellar nematocysts are most conspicuous in the newly liberated medusae, and clearly visible till the 8 th tentacle's stage. After then they gradually become indistinct, and disappear completely at the 18-20th tentacle's stage.

4) Manubrium: The stomach and the mouth of the newly liberated medusae are simple as described above. The manubrium at this stage is very short, $1 / 5-1 / 6$ the height of the subumbrellar cavity. The lower part of the stomach begins to assume a four-sided tubular shape about at the 8th tentacle's stage, then the lip margin begins to thicken at the 10th tentacle's stage. The developmental changes of the shape of the manubrium are shown in Fig. 6 Aa-Ad. At the 15-16th tentacle's stage the surface of the lip begins to become crenulate and the small spherical nematocyst knobs appear in a row along the lip margin (Fig. $6 \mathrm{Bc}$ ). The manubrium attains about half the height of the subumbrellar cavity. At the 18th tentacle's stage these nematocyst knobs have been well developed and perradial corners of the lip begin to spread outwards. The manubrium occupies about $2 / 3$ the height of the subumbrellar cavity at this stage. The lip margin begins to undulate, so that the oral view of the mouth becomes very uneven in the fully grown medusae.

5) Gonad: The first sign of gonadal rudiments appears as a translucent zone at the proximal end of the radial canals about at the 10th tentacle's stage. The rudiments gradually extend along the radial canals, and attain about $1 / 3$ the length of the latter at about the 13th tentacle's stage. The young gonad becomes thickened slightly at its distal half at about the 15 th tentacle's stage. At the 18 th tentacle's stage about $2 / 3$ of the length of the radial canal is covered with the young gonad which begins to hang down along the axis of the radial canal, assuming gradually a ribbon-like shape as shown in Fig. $6 \mathrm{Cd}$. From the 18th to the 20th tentacle's stage the gonad develops quickly and the ribbon-like gonad becomes furnished with 3-6 pleats. In fully grown mature medusae the gonads occupy nearly the whole length of the radial canals, and with 4-8 folds. 


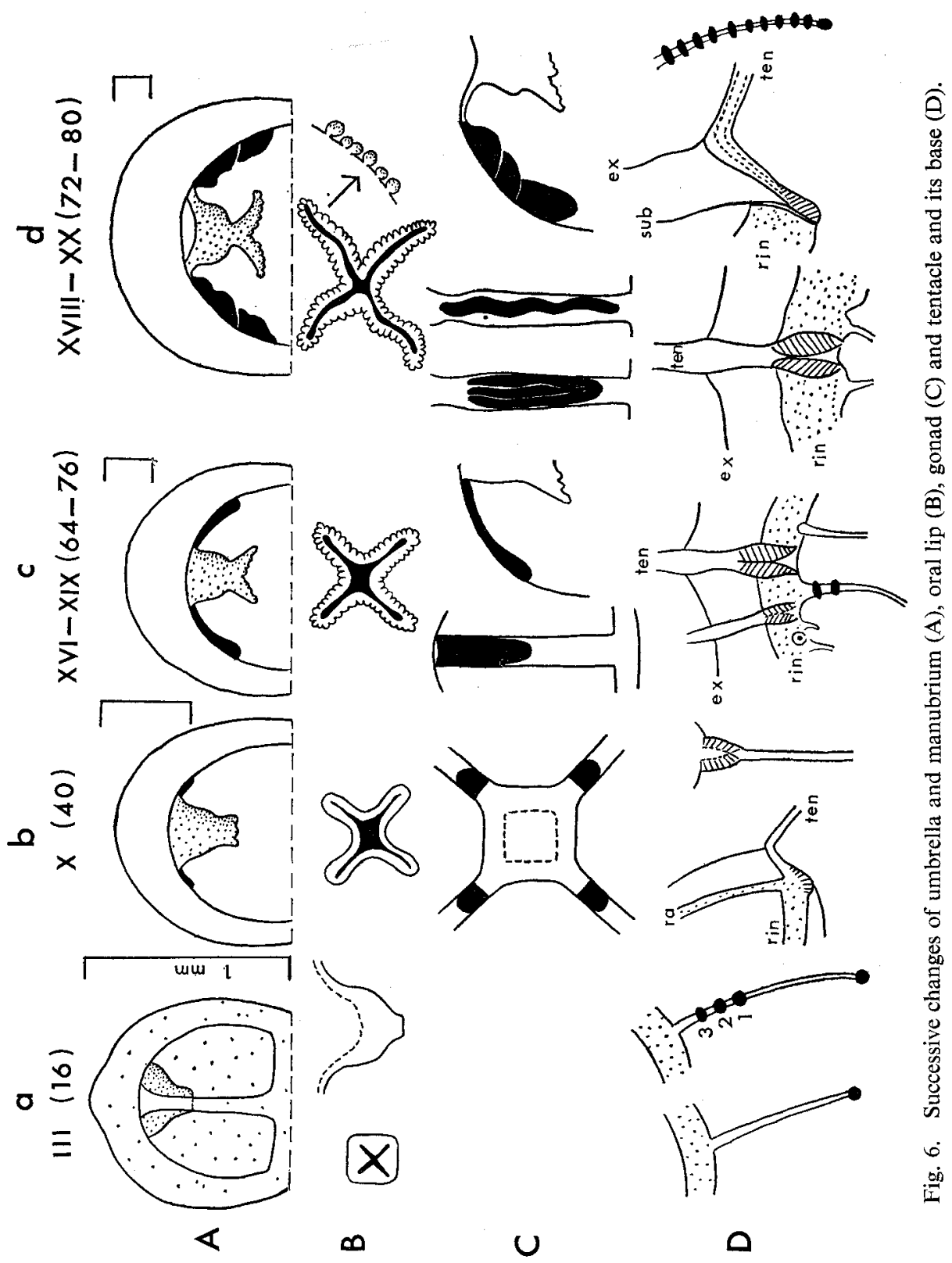

6) Tentacles and Their Base: The tentacles of the newly liberated medusae arise directly from the umbrellar margin, without any tentacle bulbs and each having only one nematocyst cluster at its terminal end. At the 8th tentacle's stage the proximal end of perradial and interradial tentacles becomes slightly swollen. The proximal end of these tentacles is then shifted slightly from the umbrellar margin. The second 
nematocyst cluster appears slightly proximally to the middle of tentacles. At the 10th tentacle's stage the third cluster develops usually proximally to the second one on the old tentacles (Fig. $6 \mathrm{Da}$ ). MACKIE and MACKIE (1963) also pointed out on a specimen from Friday Harbor, that the terminal part of the young tentacles remained free of nematocysts. The middle groove of the tentacle bulbs begins to appear at this stage in the old tentacles (Fig. $6 \mathrm{Db}$ ), while young tentacles successive to the 5 th tentacles still arise directly from the umbrellar margin. At the 13th tentacle's stage the basal end of the old tentacles begins to run upwardly and then the shaft issues at some distance above the umbrellar margin. The nematocyst clusters of the perradial and interradial tentacles increase in number to 6-11. At the 18th tentacle's stage the tentacle bulb of the old tentacles is divided wholly by the developing peroneal groove into two lateral parts each assuming a spindle shape and thus the characteristic tentacle bulb has been almost completed. The basal shaft of the tentacles runs centripetally, and then issues freely from the exumbrellar surface at some distance above the umbrellar margin. The characteristic centripetal canals have been developed between the umbrellar margin and this issuing point, the inner side of the centripetal canal being embedded in the exumbrellar jelly. The nematocyst clusters of the old tentacles come to assume a ring shape, presumably due to the thickening of the tentacles. At the 20th tentacle's stage the nematocyst rings have increased up to about 40 on the old tentacles and are distributed almost over the whole shaft. There are observed various developmental steps of the tentacle bulbs at this stage.

\section{Growth and Seasonal Occurrence}

The young medusae newly liberated are $0.7-1.0 \mathrm{~mm}$ high and about $1.0 \mathrm{~mm}$ wide. The height and the diameter of the umbrella increase rapidly with age. The growth rate during the 15 th to the 25th tentacle's stage when the gonad develops rapidly is very high. The average values of the umbrellar diameter of the successive tentacle's stages draw nearly a S-shaped curve. The biggest medusa obtained in the Akkeshi Bay was $16.5 \mathrm{~mm}$ high and $26.5 \mathrm{~mm}$ wide in the 23th tentacle's stage.

In 1965-1967, the hydroids with medusa buds were found from late April to late July. The young medusae recently liberated appeared in early May, and were continuously found till late July. From late May to June the young medusae in the $8-13$ th tentacle's stages began to appear successively and many medusae in various developmental stages were found from late July to late August. The fully grown mature medusae began to appear in August, and were found continuously till October. After late October the spent medusae with damaged tentacles increased and almost all died out in middle November. At the end of April, 1966, the water temperature in the bay was $2.5^{\circ}-7.0^{\circ} \mathrm{C}$ (average $4.9^{\circ} \mathrm{C}$ ), and gradually rose to $13^{\circ}-19.5^{\circ} \mathrm{C}$ (average $17.0^{\circ} \mathrm{C}$ ) in late August, and then gradually fell to $11.0^{\circ}-6.0^{\circ} \mathrm{C}$ (average $8.4^{\circ} \mathrm{C}$ ) in November. 
The Spawning and the Eggs: On 14 September 1966 and on 5 September 1967 many mature medusae were obtained, and were kept in glass vessels. In the next morning, respectively, many eggs had been laid, attached to the bottom of vessels. Each egg was covered with a transparent capsule-like membrane. The embryonic development proceeded within the membranous envelope. The eggs were 60-75 $\mu$ in diameter and the capsule-like membranous envelopes were 110-125 $\mu$ in diameter. Unfortunately, the embryonic development after some cleavages was disturbed by infection of some protozoans.

\section{Nematocysts}

The nematocysts (Figs. 7-15) of the hydroids and the young and adult medusae show different constitutions respectively as shown in Table 1. MACKIE and MACKIE (1963) reported two kinds of nematocysts: microbasic euryteles and heterotriches

Table 1. Nematocysts of Eperetmus typus; their distribution and size (length $\times$ width) in the state of undischarged capsules, in $\mu$.

\begin{tabular}{l|l|l|l} 
& \multicolumn{1}{|c}{ Haplonemes } & \multicolumn{2}{|c}{ Heteronemes } \\
Hydroid & Isorhizes & \multicolumn{1}{|c}{ Microbasic euryteles } & \multicolumn{1}{c}{ Macrobasic euryteles } \\
Young medusa & - & $11-13.5 \times 6-7$ & - \\
Adult medusa & $7-9 \times 3.5-5$ & $10.5-13 \times 6-8$ & $\begin{array}{l}14-20 \times 11-14 \\
\text { (Only exumbrella) }\end{array}$ \\
& $7-10.5 \times 3.5-4.5$ & $\begin{array}{l}\text { (Tentacles) } \\
13.5-16 \times 6.5-8 \\
(L i p s)\end{array}$ \\
& & $9-10 \times 5-6$ & \\
\hline
\end{tabular}

based on their examination of a medusan specimen. The size of the nematocysts of their specimen is bigger than that of the present specimens. The isorhizes of the present specimens correspond to the heterotriches by MACKIE and MACKIE. The young medusae shortly after liberation have macrobasic euryteles on their exumbrella. This kind of nematocysts were also found on the exumbrella of the young medusae of Gonionemus vertens, Gonionemus sp. and Scolionema suvaense by WERNER (1965), and of Gonionemus oshoro by the author (1969b). It seems that the existence of the macrobasic euryteles on the young medusan exumbrella is a common characteristic in the family Olindiadidae. On the one hand, the members of the genus Proboscidactyla have macrobasic euryteles throughout their life (HAND, 1954). It is probable that the fact that the macrobasic euryteles are found in nedusae of both families the Olindiadidae and the Proboscidactylidae, though temporarily in the former and lastingly in the latter, show some close affinity between the two families as also pointed out by WERNER (1965). 


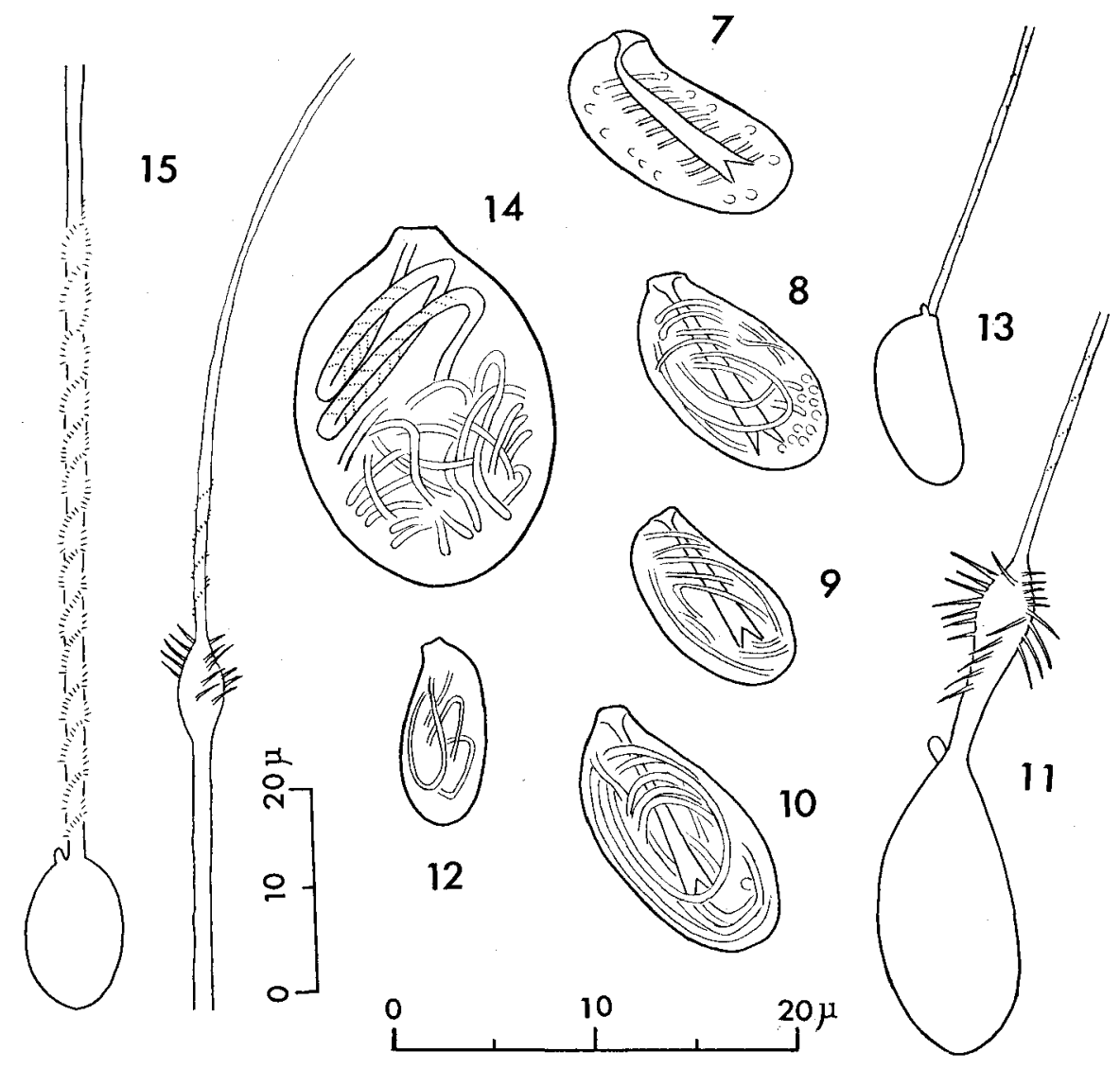

Figs. 7-15. Nematocysts of Eperetmus typus. 7-11: Microbasic euryteles of hydroid (7), young medusa (8), lip of adult medusa (9) and tentacle of adult medusa $(10,11), 12,13$ : Isorhizes of adult medusa. 14,15: Macrobasic euryteles of young medusa.

\section{Systematic Considerations}

Among the members of the family Olindiadidae the hydroid stages are known in only 5 genera as follows. Monobrachium parasitum, Gonionemus vertens, Gonionemus oshoro (=G. vertens?), Craspedacusta sowerbyi, Olindias phosphorica and Eperetmus typus (Hand, 1957; Perkins, 1903; Joseph, 1925; Kakinuma, 1971; Payne, 1924; ReISINGER, 1957; WeILl, 1936 and NAGAO, 1969a). These hydroids are all very small and very simple, without or with only one or four to six filiform tentacles. Of these, hydroids of Gonionemus, Craspedacusta and Olindias are solitary and the former two have no peridermal sheath. On the other hand, Eperetmus and Monobrachium are colonial, and are equipped more or less with the periderm-like envelope. The solitary forms, Gonionemus and Craspedacusta, are multiplied by producing planula- 
like buds or frustules. In Olindias only the primary hydroids were reared from the eggs by WeILL (1936), but regretfully, any asexual reproduction has not yet been known. The gastrozooid of Monobrachium resembles the hydroid of Eperetmus. The number and arrangement of the tentacles and marginal vesicles of the medusoid of Monobrachium coincide precisely with those of the youngest medusae of Eperetmus as pointed out in the previous paper (NAGAO, 1969a). The hydroid of Monobrachium differentiates dimorphic zooids, and is most specialized in shape among the olindiadiid hydroids. This specialization is presumably due to its commensal life on some living bivalves. The hydroid of Craspedacusta is the simplest, and its shape and developmental cycle are very similar to those of Limnocnida reported by BoulLLon (1957). UCHIDA (1963) pointed out that the simple shape of the hydroid of Craspedacusta is due to some degeneration in the fresh water life. It seems, however, that the hydroid of Craspedacusta has been adapted well to the fresh water life.

The young medusae newly or recently liberated are known in the following 10 species: Craspedacusta sowerbyi, Cubaia aphrodite, Eperetmus typus, Gonionemus oshoro, Gonionemus vertens, Gomionemus vindobonensis, Gossea corynetes, Olindias sambaquiensis, Olindias singularis and Olindias tenuis (PAYNE, 1924; BOULENGER \& Flower, 1928; Mayer, 1894; Nagao, 1969a; Kakinuma, 1971; Perkins, 1903; JoSePH, 1918; cf. RusSell, 1953; VANnuCCI, 1951; Kramp, 1965 and MAYer, 1910). We can find some common characteristics in these young medusae. Their umbrellas are nearly as high as wide and the exumbrellar nematocysts are usually conspicuous. The marginal tentacles are eight to sixteen in number. Craspedacusta, Gonionemus oshoro, Gonionemus vertens, Olindias sambaquiensis, $O$. singularis and $O$. tenuis have 8 tentacles and Gonionemus sp. examined by Kinoshita (1916) has 12 tentacles. Cubaia, Eperetmus and Gossea have already 16 tentacles. Most of them have four statocysts as in Eperetmus at the first stage of liberation, however no statocyst is found in the youngest Craspedacusta and eight statocysts have already appeared in Gossea. Besides the common characteristics mentioned above the young medusae have been differentiated in some way, especially in their tentacles. As described above the tentacles of the youngest medusae of Eperetmus have only one nematocyst cluster at the terminal end. The youngest medusae of Gossea has tentacles similar to those of Eperetmus (cf. RusselL, 1953). One half of the tentacles in Olindias sambaquiensis and $O$. singularis are the same as those in Eperetmus, while the other half have several nematocyst clusters on their shaft (VANNUCCI, 1951; KrAmP, 1965). On the other hand, all tentacles in Gonionemus, Cubaia and Olindias tenuis have already several nematocyst clusters (Perkins, 1903; JosePh, 1918; KaKinuma, 1971; MaYer, 1894, 1910). The tentacles of Gossea have been arranged in 8 groups. Of the morphology of tentacles of the youngest medusae ever known it seems probable that the most primary type is seen in Eperetmus. The two species of Olindias have partially developed tentacles. Then the most differentiated type is seen in Cubaia and Gonionemus.

While growing, the tentacles and the statocysts gradually increase in number. 
The sequence of their development was reported only in three species; Gonionemus murbachii (=G. vertens) by Perkins (1903), Gonionemus sp. and Scolionema gemifera (=S. suvaense?) by Kinoshita (1916). The KinoshitA's work was very elaborate, but was written in Japanese. In 1929 UCHIDA reproduced the principal part of KINOSHITA's report in English together with his own work on Japanese Olindiadidae. The tentacles increase in number, keeping a cyclic symmetry, in Eperetmus, Gonionemus and Scolionema. In Eperetmus the center of the cyclic symmetry is the interradial tentacle and the sequence shows a typical octantal symmetry. In Gonionemus sp. the interradial tentacles appear at the site slightly right to the interradii when viewed from the oral side, so that the left octant of respective interradial tentacles is larger than the right one. Consequently the tentacles increase more rapidly in number in the left octant than in the right one and the symmetrical pattern is modified from the typical octantal symmetry to the quadrantal symmetry. Scolionema maintained the sequense of its cyclic symmetry substantially and the center of the symmetry is the interradii as in Eperetmus, while some young tentacles of Scolionema develop isochronally in both octants.

The nematocyst surveys throughout the whole life were done in Gonionemus vertens, Gonionemus sp. and Scolionema suvaense by WERNER (1965) and in Eperetmus and Gonionemus oshoro by the author $(1969 \mathrm{a}, \mathrm{b})$. The nematocysts of the hydroid and the medusoid of Monobrachium were examined by HAND (1957) and those of the primary hydroid of Olindias phosphorica were reported by WEILL (1936). In Gonionemus murbachii $(=G$. vertens) and Gossea brachymera the nematocysts of the medusae were reported by WeILL (1934) and by RUSSELL (1938). Those of the hydroid of Craspedacusta sowerbyi were observed by Dejdar (1934) and Weill (1934). All species referred to above have microbasic euryteles commonly. Moreover, the exumbrella of the young medusae of the Olindiadidae seems to have macrobasic euryteles commonly as pointed out above. On the basis of the nematocysts the members of the Olindiadidae are considered to be rather homogenous.

There are 12 genera in the family Olindiadidae. Aglauropsis Fr. Müller 1865, Craspedacusta LANKester 1880, Cubaia MAYER 1894, Eperetmus Bigelow 1915, Gonionemus A. Agassiz 1862, Gossea L. Agassiz 1862, Maeotias Ostroumoff 1896, Monobrachium MereschKowsky 1877, Nuarchus Bigelow 1912, Olindias Fr. Müller 1861, Scolionema KishinouYe 1910 and Vallentinia BRown 1902. Of these only Monobrachium lacks free medusan stage and other 11 genera have conspicuous medusan life. As is pointed out above Monobrachium seems to be well adapted to the commensal life. The specialization of the medusae among the members of the Olindiadidae is seen mostly in the tentacles, the tentacle bulbs and the centripetal canals. The most primary type of tentacles is seen in the genus Aglauropsis. In Aglauropsis the tentacles grow evenly around the umbrella margin, and have no adhesive organs. Moreover, MoreIra and Yamashita (1972) pointed out that the gonads of Aglauropsis kawari are continuous to the corners of stomach wall. Tentacles of the type seen in $A g$ - 
lauropsis is found in Nuarchus, while Nuarchus has six radial canals. In Eperetmus the arrangement of the tentacles is the same as in Aglauropsis, but the old tentacles of Eperetmus issue at some distance above the umbrellar margin and the centripetal canals have developed between the issuing points of tentacles and the umbrellar margin. In Maeotias true centripetal canals grow, but maintaining the tentacles of the same type as in Aglauropsis. On the other hand, the tentacles of Gossea grow in groups. In Craspedacusta the arrangement of tentacles is similar to that of Aglauropsis, but the nematocyst arrangement on the tentacle differs from that of other genera. The tentacles of the genera mentioned above are composed of one kind without adhesive organs. The genera Vallentinia, Cubaia and Olindias have two kinds of tentacles, one of them has an adhesive organ and the other has only nematocysts rings on its shaft. Of these genera, Vallentinia has no centripetal canal and the tentacles with adhesive organ are only four to eight in number. The tentacles with adhesive organ of Cubaia issue at some distance above the umbrellar margin, and about 20 in number. True centripetal canals are seen in Olindias. In Scolionema and Gonionemus all tentacles have an adhesive organ. In Scolionema the adhesive organs are weakly developed and the statocysts are only 16 in number. Among these medusae, Olindias and Gonionemus have wide range in their distribution, and speciation takes place in them in higher degree; namely Olindias has differentiated into seven species and Gonionemus has three species with some subspecies or varieties. It seems probable to consider that Gonionemus has been highly adapted to the littoral life. On the one hand, Craspedacusta has been well adapted to the fresh water life, and has been distributed all over the world. From the above-given facts a possible figure of the differentiation of the genera of the family Olindiadidae is presented tentatively as follows.

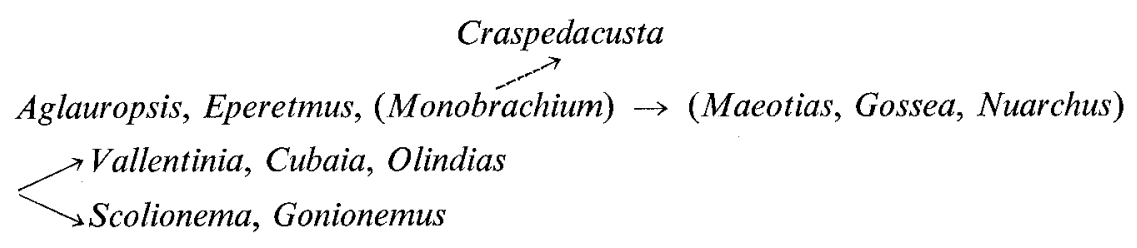

For more reasonable considerations on the differentiation of the Olindiadidae further studies of the life history in many other genera will be required.

\section{Summary}

1. The hydroid of an olindiadiid medusa, Eperetmus typus, grows to a small colony on empty shells in Akkeshi Bay. The hydroid is very small, and has only one filiform tentacle.

2. The young medusae newly liberated from the hydroid have 16 tentacles, 4 marginal vesicles, but no centripetal canals.

3. The tentacles and the marginal vesicles increase in number maintaining a 
cyclic symmetry in each quadrant. The umbrella becomes flattened with age. The gonadal rudiments appear at about the 10th tentacle's stage. The young gonads grow along the radial canals, and are gradually thickened. The characteristic centripetal canals develop gradually with the upward shift of the issuing points of tentacles, after about the 13th tentacle's stage.

4. In Akkeshi Bay the young medusae recently liberated occur from May to July. The spawning takes place mostly in September and spent medusae die out in November.

5. The constitution of nematocysts differs in respective life stages; the young medusae have macrobasic euryteles on their exumbrella.

6. The systematic considerations on the members of the family Olindiadidae are made on the basis of the life cycle, the nematocysts and the tentacles of grown medusae.

\section{Acknowledgements}

The author wishes to express his sincere thanks to Prof. Emer. Tohru UCHIDA and Prof. Mayumi YAMADA, Hokkaido University, for thir valuable suggestions and encouragement.

\section{REFERENCES}

Bigelow, H. B. 1915. Eperetmus, a new genus of Trachomedusae. Proc. U. S. Nat. Mus., 49: 399_ 404, Pl. 59.

1920. Medusae and ctenophores from the Canadian Arctic Expedition, 1913-18. Rep. Canad. Arct. Exped., 8, H: 1-20, Pls. i, ii.

Bouillon, J. 1957. Etude monographique de genre Limnocnida (Limnoméduse). Ann. Soc. Royale Zool. Belg. 87: 254-500.

Boulenger, C. L. and W. U. Flower 1928. The Regent's Park medusa, Craspedacusta sowerbii, and its identity with C. (Microhydra) ryderi. Proc. Zool. Soc. London, 66: 1005-1015, Pl. I.

DEJDAR, E. 1934. Die Süsswassermeduse Craspedacusta sowerbii LANKESTER in monographischer Darstellung. Z. Morph. Ökol. Tiere, 28: 595-691.

Foerster, R. E. 1923. The hydromedusae of the west coast of North America, with special reference to those of the Vancouver Island region. Contr. Canad. Biol. Fish., N. S., 1: 221-277, Pls. I-V.

HaND, C. 1954. Three Pacific species of "Lar" (Including a new species), their hosts, medusae, and relationships (Coelenterata, Hydrozoa). Pacific Sci., 8: 51-67.

1957. The systematics, affinities, and hosts of the one-tentacled, commensal hydroid Monobrachium, with new distributional records. J. Washington Acad. Sci., 47: 84-88.

JosepH, H. 1918. Ein Gonionemus aus der Adria. S.B. Akad. Wiss. Wien. Math.-Naturw. K1., Abt. I, 127: 95-158, 1 Pl.

1925. Zur Morphologie und Entwicklungsgeschichte von Haleremita und Gonionemus. Ein Beitrag zur systematischen Beurteilung der Trachymedusen. Z. Wiss. Zool., 125: 374-434, Taf. VIII.

Kakinuma, Y. 1971. Life cycle of a hydrozoan, Gonionema oshoro UchidA. Bull. Mar. Biol. Stat. Asamushi, Tôhoku Univ., 14: 91-97, Pls. III-VII.

KinoshitA, K. 1916. On the arrangement and development of tentacles and statocysts in two craspedote medusae. (In Japanese.) Zool. Mag. (Tokyo), 28: 425-451.

Kramp, P. L. 1965. The hydromedusae of the Pacific and Indian Oceans. Dana Rep., 63, pp. 1-162. 
MACKIE, G. O. and G. V. MACKIE 1963. Systematic and biological notes on living hydromedusae from Puget Sound. Nat. Mus. Canada Bull., 199: 63-84.

MAYer, A. G. 1894. An account of some medusae obtained in the Bahamas. Bull. Mus. Comp. Zool. Harv., 25: 235-242, Pls. 1-3.

1910. Medusae of the World, Vol. II, The hydromedusae. 498 pp. Washington.

Moreira, G. S. and C. Yamashita 1972. Aglauropsis kawari (Limnomedusae: Olindiasidae), a new species from the South Atlantic Ocean. Mar. Biol., 14: 271-274.

NAGAO, Z. 1969a. The life history of Eperetmus typus Brgelow (Limnomedusae, Olindiadidae). Bull. Mar. Biol. Stat. Asamushi, Tôhoku Univ., 13: 235-240.

1969b. The nematocysts and the life-cycles of some hydromedusae. (In Japanese with English abstract.) Proc. Jap. Soc. Syst. Zool., 5: 37-41.

Payne, F. 1924. A study of the fresh-water medusa, Craspedacusta ryderi. J. Morph., 38: 387-430, Pls. 1-10.

Perkins, H. F. 1903. The development of Gonionema murbachii. Proc. Acad. Nat. Sci. Philad., 54: 750-790, P1s. XXXI-XXXIV.

REISINGER, E. 1957. Zur Entwicklungsgeschichte und Entwicklungsmechanik von Craspedacusta (Hydrozoa, Limnotrachylina). Z. Morph. Ökol. Tiere, 45: 656-698.

Russell, F. S. 1938. On the medusa Gossea brachymera Bigelow. Proc. Zool. Soc. Lond. Ser. B 108: 707--710, P1. 1.

1953. The Medusae of the British Isles. 530pp, 35 Pls. Cambridge.

UCHid, T. 1929. Studies on Japanese hydromedusae: 3 Olindiadae. Annot. Zool. Japon., 12: 351-372, Pl. 1.

1940. The fauna of Akkeshi Bay XI. Medusae. J. Fac. Sci. Hokkaido Univ., Ser. VI, Zool., 7: 277-297.

___ 1963. The systematic position of the Hydrozoa. Jap. J. Zool., 14: I-14.

VannucCi, M. 1951. Hydrozoa e Scyphozoa existentes no Instituto Paulista de Oceanografia. Bol. Inst. Paulista de Oceano., 2: 69-100, 4 Pls.

WEILL, R. 1934. Contribution à l'étude des cnidaires et de leurs nématocystes. II. Valeur taxonomique du cnidome. Trav. Stat. Zool. Wimereux, 11:349-701.

1936. Existence de larves polypoïdes dans le cycle de la Trachyméduse Olindias phosphorica Delle Chiaje. C. R. Acad. Sci. Paris, 203: 1018-1020.

Werner, B. 1965. Die Nesselkapseln der Cnidaria, mit besonderer Berücksichtigung der Hydroida I. Klassifikation und Bedeutung für die Systematik und Evolution. Helgol. Wiss. Meeresunters., 12: 1-39.

\section{DISCUSSION}

WeILL: I wonder that I did not observe macrobasic euryteles in the Gonionemus murbachi (VERTENS) specimens I studied.

WERNER: Those nematocysts exist only in young and newly liberated medusae, and disappear in a few weeks.

WERNER: 1) Have the polyps of Eperetmus a periderm? 2) Do you believe that the number of one tentacle of the polyp represents a primitive or progressive mark?

NAGAO: 1) Yes, they have a very thin membranous sheath below the tentacle. 2) I think that hydroids with one tentacle are generally more primitive than those with several or many tentacles. However, in the Olindiadidae, I am not sure about this, because the hydroid stage has been known only in five genera of this family. Moreover, the hydroid has no tentacle, while the medusa is seemingly rather progressive, in Olindias. 